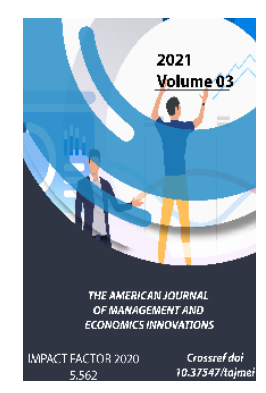

\title{
Integration Of Science And Education As An Important Factor In Improving The Quality Of Education
}

\author{
Urinov Dilshodjon Akhmadjonovich \\ Researcher, Fergana State University, Uzbekistan
}

Journal Website:

https://theamericanjou

rnals.com/index.php/ta

jmei

Copyright: Original

content from this work

may be used under the

terms of the creative

commons attributes

4.0 licence.

\section{ABSTRACT}

The article discusses the role of higher education institutions in improving the quality of education, the involvement of teachers in research activities and the involvement of students in this process is an important factor in improving the quality of education. Also, the analysis of the results of scientific activity of professors of higher education institutions and forecasts for future periods were made.

\section{KEYWORDS}

Education, Science, Quality Of Education, Higher Education, Scientific Activity, Results Of Scientific Activity.

\section{INTRODUCTION}

In the current context of rapid changes in all spheres of social and economic life, highly qualified personnel with modern knowledge and high moral and ethical qualities, who can quickly master the knowledge associated with these changes, adapt the acquired knowledge to changing conditions, apply all reforms in our country. is the decisive force that provides [1]. The training of such personnel is directly related to improving the quality of education in the higher education system. After all, the first and most important factors determining the quality of education are highly qualified teachers working in this system, who are trained in higher education institutions [2].

The role of higher education institutions is expanding in a knowledge-based economy that requires extensive use of scientific advances in all areas. Along with the task of higher education institutions to create new knowledge, which is traditional for them, to 
collect it and pass it on to future personnel, the task of engaging in scientific activities and directing the results of this activity to solving existing problems in society is considered more and more important.

Therefore, in developed countries with innovative economies, universities are seen as a "catalyst" for economic development. At present, the law stipulates that in higher education institutions of the Republic of Uzbekistan, along with the educational process, scientific activities must be carried out, and the teaching staff of higher education institutions must be engaged in scientific activities in relevant areas [3].

The ability of professors to engage in scientific activities and effectively implement the results of these activities in practice is important in the effective organization of the educational process. This importance stems from the fact that professors are aware of the real problems that exist in practice in the areas in which they teach, and are able to provide effective solutions to these problems using theoretical knowledge. At the same time, ensuring that students participate in these processes helps them develop practical skills. The involvement of professors in scientific activities, the implementation of its results in practice and the involvement of students in this process:

- Improving the quality and efficiency of the educational process;

- Development of scientific thinking in students;

\footnotetext{
${ }^{1}$ Calculated by the author on the basis of reports of the Intellectual Property Agency of the Republic of Uzbekistan for 2012-2017.
}

- Increase the scientific potential of teachers;

- Strengthening the "teacher-student" school and traditions, the formation of a talented future generation of researchers;

- Serves to train highly qualified specialists in the priority areas of science and technology development and ensures the integral connection of science and education [4].

In Uzbekistan, the inadequacy of forecasting the results of scientific activity, economic analysis is considered as one of the existing problems in the field of science and needs to be addressed. Given that the effective solution of such problems will serve not only the development of science, but also to increase the effectiveness of education in the future, it is important to analyze the results of scientific work of professors in higher education and use this analysis to improve the quality of education.

An analysis of the number of applications for intellectual property submitted by higher education institutions of the country shows that this figure is more than $8 \%$ of the total number of registered intellectual property in the country ${ }^{1}$. Comparing this figure with the number of professors working in higher education institutions, an average of 18 intellectual property applications per 1,000 professors ${ }^{2}$.

When analyzing the dynamics of the number of organizations that have introduced

\footnotetext{
${ }^{2}$ Calculated by the author on the basis of data of the Statistics Committee of the Republic of Uzbekistan and reports of the Intellectual Property Agency of the Republic of Uzbekistan for 2012-2017
} 
technological, marketing and organizational innovations, we can see that the number of these organizations is growing in other regions of the country. In particular, in 2009, 53.6\% of these organizations were located in Tashkent, and in 2018 it was 22\%. At the same time, growth can be seen in Navoi and Tashkent regions ${ }^{3}$.

At present, funding for science and research is only $0.16 \%$ of the country's GDP, which is almost 10 times less than the amount of money allocated to science by a number of developed and developing countries. The share of scienceintensive products and the amount of money spent on science in relation to the gross domestic product are the main indicators of a knowledge-based economy.

This figure is currently $4.2 \%$ in South Korea, 3.5\% in Japan, $2.9 \%$ in Germany, $2.8 \%$ in the United
States, $2.2 \%$ in France, $2.1 \%$ in China and $1 \%$ in Russia [5].

In order to carry out the analysis, the objects of intellectual property registered as the main result of the scientific activity of professors of higher education institutions and the expenditures allocated for research from the state budget for scientific activities were selected.

Modeling the dynamics of key indicators in the field of innovation transfer in higher education institutions in the Republic of Uzbekistan can be done using models such as trends, tendencies and time series. We analyzed the trends of change over the years by studying some indicators related to the transfer of innovations in higher education institutions (Table 1).

Table 1

The dynamics the number of intellectual property objects registered in the higher education system of the Republic of Uzbekistan and influencing factors ${ }^{4}$

\begin{tabular}{|c|c|c|c|}
\hline Year & $\begin{array}{c}\text { Number of } \\
\text { intellectual property } \\
\text { objects registered by } \\
\text { universities, unit }\end{array}$ & $\begin{array}{c}\text { Expenditures on research } \\
\text { and development in the } \\
\text { higher education system, } \\
\text { mln. soums }\end{array}$ & $\begin{array}{c}\text { Number of organizations } \\
\text { that have introduced } \\
\text { technological, marketing } \\
\text { and organizational } \\
\text { innovations, units }\end{array}$ \\
\hline 2012 & 122 & 27612,4 & 187 \\
\hline 2013 & 92 & 34956,6 & 761 \\
\hline 2014 & 101 & 53565,7 & 852 \\
\hline
\end{tabular}

${ }^{3}$ Calculated by the author on the basis of data from the Statistics Committee of the Republic of Uzbekistan.

4 Developed on the basis of data from the State Statistics Committee of the Republic of Uzbekistan and the Intellectual Property Agency of the Republic of Uzbekistan. 
The American Journal of Management and Economics Innovations (ISSN - 2693-0811)

Published: October 30, 2021 | Pages: 21-27

Doi: https://doi.org/10.37547/tajmei/Volume03Issue10-06

\begin{tabular}{|l|l|l|l|}
\hline 2015 & 265 & 65029,2 & 935 \\
\hline 2016 & 309 & 82424,6 & 933 \\
\hline 2017 & 356 & 90177,2 & 1023 \\
\hline 2018 & 428 & 88892,2 & 1024 \\
\hline 2019 & 515 & 87647,7 & 1082 \\
\hline
\end{tabular}

On the basis of trend models, the number of intellectual property objects registered by higher education institutions in the Republic of Uzbekistan in 2020-2022 and the future indicators of changes in the influencing factors and the list of the most convenient functions for their calculation are given (Tables 2, 3).

We determined that the number of intellectual property objects registered by universities in Uzbekistan depends on the amount of expenditures on research and development in the higher education system and the number of organizations that have introduced technological, marketing and organizational innovations. We found that the change in the number of intellectual property registered by universities $(Y)$ depends on the highest influencing factors, and these factors include the amount of expenditures on research and development in higher education $\left(X_{1}\right)$ and organizations that have introduced technological, marketing and organizational innovations. number $\left(X_{2}\right)$ was selected. Using the identified data, a multi-factor econometric model of the change in the number of intellectual property registered by universities under the influence of factors affecting it was developed.

In the model of change in the number of intellectual property objects registered by universities: $\mathrm{a}_{0}=-68,133 ; \mathrm{a}_{1}=0.007 ; \mathrm{a}_{2}=-0.145$. According to this, representing this process

$$
y=0,007 \cdot x_{1}-0,145 x_{2}-68,133(1)
$$

(1)-regression equation was constructed. 
Table 2

Trend models of the number of intellectual property objects registered in the higher education system of the Republic of Uzbekistan and the indicators of the influencing factor ${ }^{5}$

\begin{tabular}{|c|c|c|}
\hline № & Indicator & Model \\
\hline 1. & $\begin{array}{c}\text { Number of intellectual property objects } \\
\text { registered by universities, unit }\end{array}$ & $y=0,007 \cdot x_{1}-0,145 x_{2}-68,133$ \\
\hline 2. & $\begin{array}{c}\text { Expenditures on research and development in } \\
\text { the system of higher education, mln. soums }\end{array}$ & $x_{1}=17965,68 \cdot t-41744,69$ \\
\hline 3. & $\begin{array}{c}\text { The number of organizations that have } \\
\text { introduced technological, marketing and } \\
\text { organizational innovations }\end{array}$ & $x_{2}=17965,68 \cdot t-41744,69$ \\
\hline
\end{tabular}

The reliability and adequacy of the constructed model should be checked on the basis of several criteria to ensure the accuracy of the results. Since there is no autocorrelation in the identified trend and it meets the demand for other criteria as well, the above-defined regression equation (1) was found to be reliable and proved to be adequate.
The prognosis of the change in the volume of services was determined by substituting the models representing the change in the indicators determined by the time factor for the corresponding variables in the (1) regression equation (Figure 1 ).

\footnotetext{
${ }^{5}$ Developed by the author.
} 
Table 2

Forecast of number of intellectual property objects registered in the higher education system of the Republic of Uzbekistan and indicators of influencing factors ${ }^{6}$

\begin{tabular}{|c|c|c|c|c|}
\hline \multirow{2}{*}{ № } & \multirow{2}{*}{ Inducator } & \multicolumn{3}{|c|}{ Year } \\
\hline & & 2020 & 2021 & 2022 \\
\hline 1. & $\begin{array}{c}\text { Number of intellectual property objects registered } \\
\text { by universities, unit }\end{array}$ & 516 & 570 & 624 \\
\hline 2. & $\begin{array}{l}\text { Expenditures on research and development in the } \\
\text { system of higher education, mln. soums }\end{array}$ & 110064,4 & 119792,4 & 129520,4 \\
\hline 3. & $\begin{array}{l}\text { The number of organizations that have introduced } \\
\text { technological, marketing and organizational } \\
\text { innovations, unit }\end{array}$ & 1283 & 1379 & 1475 \\
\hline
\end{tabular}

The above analysis allows us to assess and predict the overall effectiveness of the number of intellectual property registered by universities. An orderly analysis of the factors influencing the key indicator in assessing the prospects of the number of intellectual property registered by universities can clearly show the future prospects of the field of creation and registration of intellectual property in universities.

Based on the above-mentioned scientific considerations, discussion of ideas, theoretical views, observations, research, the following conclusions and recommendations were made:

- The quality of teaching staff in the education system is the most important factor in improving the quality of education, and the effectiveness of reforms in higher education institutions that train these staff is crucial;

- Conducting the educational process in conjunction with the process of implementing science and its results in practice will serve to improve the quality of education. In this case, the connection between theory and practice is ensured, the achievements of science are directed to the solution of clearly defined problems, serve for the formation of scientific thinking in students;

- The possibility of obtaining financial resources as a result of the introduction of research results into production creates an opportunity for students to develop innovative entrepreneurial skills.

\footnotetext{
${ }^{6}$ Calculated by the author.
} 
In short, the integration of education and science serves to improve the quality of education.

\section{REFERENCES}

1. "On approval of the Concept of development of the higher education system of the Republic of Uzbekistan until 2030". Decree of the President of the Republic of Uzbekistan dated 08.10.2019 N PF-5847.

2. Shmyreva N.A., Gubanova M.I., Kretsan Z.V. Pedagogical systems: scientific basis, management, development perspectives. - Kemerovo, 2002. p. 100

3. "On science and scientific activity". Law of the Republic of Uzbekistan. October 29, 2019, No. ORQ-576

4. "On science and scientific activity". Law of the Republic of Uzbekistan. October 29, 2019, No. ORQ-576 